\title{
Historical Processes and the Political Organization of the Hasinai Caddo Indians
}

Daniel A. Hickerson

University of Georgia

Follow this and additional works at: https://scholarworks.sfasu.edu/ita

Part of the American Material Culture Commons, Archaeological Anthropology Commons, Environmental Studies Commons, Other American Studies Commons, Other Arts and Humanities Commons, Other History of Art, Architecture, and Archaeology Commons, and the United States History Commons

Tell us how this article helped you.

This Article is brought to you for free and open access by the Center for Regional Heritage Research at SFA ScholarWorks. It has been accepted for inclusion in Index of Texas Archaeology: Open Access Gray Literature from the Lone Star State by an authorized editor of SFA ScholarWorks. For more information, please contact cdsscholarworks@sfasu.edu. 
Historical Processes and the Political Organization of the Hasinai Caddo Indians

Creative Commons License

(c) (1) \& 8

This work is licensed under a Creative Commons Attribution-NonCommercial 4.0 International License 


\title{
HISTORICAL PROCESSES \\ AND THE POLITICAL ORGANIZATION OF THE HASINAI CADDO INDIANS
}

\author{
Daniel A. Hickerson, The University of Georgia \\ Paper presented at the 1995 Caddo Conference, Austin, Texas
}

Recent archaeological and ethnohistoric research has begun to reveal the extent of the depopulation that took place among Native American societies as a result of epidemic diseases that were introduced, in some cases, even before direct continuous interaction with Europeans. The research of Henry Dobyns (1983) on native demographic trends in Florida has been particularly influential on recent views of Native American demographic decline. While somewhat controversial, the findings of Dobyns and others have stimulated further research focusing on other areas of North America, including the Caddoan region.

Recently, Timothy Perttula (1991, 1992) has focused on the role of European-introduced epidemic diseases in changes in settlement patterns and sociopolitical organization among the native peoples of the Caddoan region. Drawing largely upon Dobyns' figures and models for native depopulation, Perttula has estimated up to a 95 percent decline among the Caddoan population during the protohistoric period (approximately 1520-1680). According to Perttula, this depopulation had a number of sociocultural consequences, including a general decline in political complexity, and the abandonment of some regions accompanied by a coalescence of groups in several areas, including that occupied by the historic Hasinai of the Neches and Angelina River basins of eastern Texas.

It is not the purpose of this paper to take issue with the points that have been made by Perttula or any other scholar doing research on the effects of introduced epidemic diseases. Indeed, it is because of such research that it is no longer possible to reasonably deny or overlook the fact that the cultures of the native peoples of North America as they were first described by Europeans had, in most cases, been drastically altered. It is only in the past few years that anthropologists and historians have fully understood the difficulties involved in reconstructing precontact cultures and societies based on European descriptions alone.

However, as important as it is to recognize the impact of introduced pathogens, it is equally important to avoid overstating their impact on native societies. Once the disease factor has been recognized, it is tempting to attribute to it every cultural change, every protohistoric or historic population movement, every shift in settlement or subsistence patterns, or in political or economic life, for which evidence is found. This can be dangerous for at least two reasons: first, because, despite the quality of recent archaeological work focusing on disease, we are still far from establishing the true extent of demographic decline in the Caddoan region; and second, because the protohistoric period in this region ( $\mathrm{ca}$. 1520-1680) was characterized by a number of large-scale processes of change, each of which culturally impacted local populations over a wide area, and only one of which was the introduction of epidemic diseases to the New World.

In other words, we should view disease within a larger context, as one of several large-scale processes of change that resulted directly or indirectly from European activity in North America and Mesoamerica. Each of these histori- 
cal processes contributed to sociocultural changes among the Caddo and other Native American peoples. Even where disease plays a significant and documented role in a sociocultural change, it can not entirely determine how the change is played out. For example, the spread of disease may have brought about the abandonment of some areas in North America, but other social, political, and environmental factors may have played a role in determining or influencing where the survivors moved after the abandonment.

I will begin with the premise that the Hasinai area of eastem Texas was the site of a protohistoric population coalescence, that the core of the historic Hasinai Confederacy was a combination of groups or communities long resident in the area, and that these were joined by other Caddoan communities during the protohistoric peri- od, possibly during the mid- to late-seventeenth century. The spread of epidemic disease may have been one of the events that brought about pressure for such a coalescence. However, during the protohistoric and early historic periods there were other processes of political and economic change taking place, originating many miles away, with far-reaching impacts. In addition, there were social and environmental factors other than disease that influenced the movements of groups of people, that influenced both whether or not they moved their settlements, and to what destination. In this paper I will briefly discuss the role of disease in protohistoric population movements. I will then focus attention on additional factors such as warfare and trade, and discuss how changes in these factors combined to influence the creation of the historic alliance that is known as the Hasinai Confederacy.

\section{The Role of Epidemic Disease}

It is important that regional estimates of native population decline be applied critically and with attention given to regional differences in environment, extent of European contact, and settlement patterns. As noted, a major demographic decline, with a population loss due to introduced diseases of up to 95 percent in the Caddo culture area, has been hypothesized for the protohistoric period, A.D. 1520-1680 (Perttula 1992). But Perttula (1992:77) also reminds us that the archaeological evidence for such a decline is far from adequate to draw firm conclusions about population trends during this period. The specific evidence that does exist for the Caddo area is almost entirely indirect and inferential, based on analysis of generally inadequate regional settlement data, changes in mortuary practices and regional settlement patterns indicating declining sociopolitical complexity, and comparisons with data on population declines in neighboring regions.

Perhaps more important than evidence of largescale, regional rates of population decline, at least in the context of the present discussion, is the near certainty that areas throughout the Southeast, including the Caddoan region, were affected differentially by European-introduced epidemic diseases. Of course, local populations were most likely to be devastated by epidemic disease immediately after they experienced direct contact with Europeans. In the long run, differences in the impact of diseases more likely reflect variations in settlement densities, such as those between upland or rural communities and larger riverine or town communities (Perttula 1992:79, 87-89).

When drawing comparisons with the demographic trends elsewhere in the protohistoric Southeast, it must be kept in mind that settlements in the Caddoan area were, in general, more dispersed and less densely populated than the Mississippian period settlement systems of the Southeast, and thus likely to be less susceptible to the spread of epidemics. For the same reason, within the Caddoan culture area, the populations of eastern Texas, particularly those 
of the relatively lightly-settled Hasinai area, appear to have been relatively lightly impacted by introduced diseases during the protohistoric period. The de Soto party, which passed through the Caddoan area around the time that the major epidemics in North America would have begun, found settlements that were described as more scattered, and thus less densely populated, than those that it had previously encountered throughout the Southeast. This trend was first noted upon their passage through Naguatex, located on the Red River and their point of entrance into eastern Texas (Gentleman of Elvas, in Smith, 1925:240-245).

Epidemics of introduced diseases might be sufficient to explain the abandonment of, or significant demographic reduction in, some areas, and the concentration of settlements in others, such as the Arkansas, Ouachita, and Red River regions, during the protohistoric period. However, given available information, comparisons of settlement patterns and epidemic disease trends are not adequate to explain the abandonment of the less densely populated Cypress Creek basin toward the end of the protohistoric or the very early historic period (Thurmond 1985; McCormick 1973:108). Nor do these factors adequately explain the coalescence of population around this time along the Neches and Angelina rivers, the site of the historic Hasinai Confederacy.

It is reasonable to suggest that the groups that had formerly inhabited the Cypress Creek area were among those that came to comprise the Hasinai Confederacy. If I am correct in this suggestion, then reasons other than epidemic disease must be sought to explain the movement of these people to join their southern neighbors. Previous archaeological research has provided no reason to suppose that the impact of epidemics was any more (or less) severe in the Cypress Creek region than in the Hasinai region. Dobyns (1983:311) has suggested that the amalgamations of surviving populations would take place in the most productive environments for native subsistence technology. I would concede that ecological and demographic conditions would have certainly had some degree of influence, but suggest that economic and political factors must also be sought to account for the coalescence of populations in the Neches River valley area. The interaction of these factors will be the primary subject of the remainder of this paper.

\section{Historical Influences on Population Movements}

I suggest that one political factor that influenced population movements during the protohistoric period is warfare -- specifically, the increased aggression by the Apaches in the southern Plains. The aggression of Apache Indians was a major concern for the Hasinai and their neighbors, and violent encounters that frequently took place with the Apaches were noted by nearly all of the European observers who lived for an extended time among the Hasinai. It is important to understand that, although the Spanish priests believed the wars between the Hasinai and the Apaches to be the result of the "ancient hostility between them" (Hidalgo, in Hatcher 1927:55), the rise of the Apaches as a major threat to the settled tribes at the margins of the plains was actually, as of the late seventeenth century, of quite recent origin. Before the seventeenth century, the Apaches wandered the plains on foot, hunting bison and other game, and trading with the Pueblo peoples who lived along the Rio Grande to the west of the plains. Indeed, it appears that the Apaches only became a significant threat to their eastern neighbors around the middle of the 1600 's. The development that created this threat took place several hundred miles to the west, with the introduction of the horse into New Mexico by the Spanish colonists who occupied the Rio Grande valley. 
The first horses, and the knowledge required to ride and maintain them, were probably acquired by the Apaches through trade with Puebloan Indians who had been employed, or forced, to care for the horses of the Spanish colonists. The possession and mastery of those first horses gave the Apaches the means to build up their supplies through raiding, and by 1660 Apaches were taking horses in frequent attacks on the Spanish and Puebloan Indian settlements in New Mexico (Newcomb 1961:86-87). It was around this time that the Apaches acquired their reputation among the Spanish as the fearsome and hostile warriors who dominated the southern Plains, a reputation that stayed with them through the eighteenth century.

Horses, along with Spanish weapons acquired in New Mexico, made the Apaches a serious threat to the settled agricultural villages occupied by Caddoan Indians on the eastern fringe of the plains. They became, in the words of one Spanish observer, "enemies of one and all"' on and near the plains. Father Damian Massanet, a Franciscan missionary who worked among the Hasinai, reported in 1691 that the Apaches "are at war with all the other nations. . . . they dominate all the other Indians" (Hatcher 1932: 58). Other tribes that had lived on the southern plains, and had served as a buffer between the Apaches and the Caddoan groups, had been driven south and west by the 1680's, as the Apaches expanded across the entire width of the plains (Hyde 1959:43). In 1686, Alonso de Posada (Thomas 1982:36-38) described the Apache nation, "which possesses and is owner of all the plains of Cibola [the southern Great Plains]." Posada noted that the Apaches were at war with the Hasinai, and listed several nations, including the Jumanos, that they had driven from the region of the Nueces River, southward to the Rio Grande.

The Wichita and the Pawnee, Caddoan Indians who lived farther west on the plains in farming villages along the river valleys, thus were more exposed to attack, and seem to have fared worse at the hands of the mounted raiders than did the
Hasinai. In the later decades of the seventeenth century, Apaches began bringing Caddoan captives, mostly Wichita and Pawnee, to sell or trade at trading fairs in Pecos, Taos, and Picuris pueblos. These captives were traded there as slaves, primarily in exchange for Spanish daggers, hatchets, and sword blades of metal (Hyde 1959:20). Posada (Thomas 1982:36-37) noted that the Apaches regularly came to Pecos Pueblo "to sell for horses some Indian men and women, girls and boys, whom they had captured from the Quivira nation in attacks they had made upon their lands." The Quivira have been identified as the Wichita (N.P. Hickerson 1994:24).

The Hasinai began to acquire horses and Spanish weapons of their own some time before the 1680 's. This allowed the Hasinai and their allies to meet the Apache on a more equal footing, and occasionally to take the offensive in battle. However, at the same time, they were also actively seeking allies to stand with them in these battles. In the eyes of Hasinai leaders, these potential allies included European newcomers. In 1687, according to Father Douay of the La Salle party (Cox 1973, v. 1:241), a party of Hasinais persuaded some of the French colonists to join them in battle with the Canoatinno, which may have been an Apache group living on or near the Colorado River (Hyde 1959:43). Indeed, military alliance may have been expected, even assumed, of the friends and neighbors of the Hasinai. A few years later, in a letter of 1693 , the Franciscan priest Damian Massanet (1964:313) noted among the reasons for the dissatisfaction that the Hasinai had with the Spanish, that "they have said many times that if we do not go with them to their wars and to kill their enemies, that we should return to our land."

The rise of hostility between the Hasinai and the Apache on the southern Plains, and the resulting increased danger from raiding and warfare, are likely to have exerted pressure on the Hasinai and their neighbors, both Caddoan and non-Caddoan, to seek close alliances and in some instances to concentrate their settlements for the benefit of mutual protection. This factor 
alone, however, does not explain the selection of the region of the Neches and Angelina Rivers, the homeland of the Hasinai, as the site of a population coalescence. For this purpose, we must look to the environmental characteristics of this homeland, and the possible consequences of the position of the Hasinai within this region. The position of the Hasinai in the woodlands along the Neches and Angelina rivers provided a measure of protection from mounted raiders of the plains, both because of the remoteness and the terrain of the region. The threat from the Apaches, and other real or potential enemies, may have been a significant factor that determined or influenced the movement of populations into this area during the seventeenth century.

The dense forest that covered most of the land in this area was a barrier to travel by any means, but especially to horseback warriors wishing to strike suddenly and then retreat quickly. The advantages of this protective barrier were noted by European observers. In 1690, Father Massanet (Gomez Canedo 1968:161) described the two roads from the south by which the Hasinai could be reached. The first road, he said, "goes straight north to the Texas. But the Apaches are in the habit of coming to it, and these Apaches are enemies both of the Texas [i.e., the Hasinai] and of the Spanish." The second road ran to the northeast, and was described by Massanet as "more secure, because there are no enemies, nor do the Apaches come to it because of the dense forest and the distance."

The density of the forest was at times a source of frustration to the Spanish, as well as to Indian enemies of the Hasinai. Teran de los Rios, in 1691 , expressed such frustration in seeking a place for his army to camp, noting, "no suitable place was found within the radius of twelve leagues; for there is no open country nearby. . . The whole country is wooded to a distance of about twenty-five leagues from this spot" (Hatcher 1932:18). Espinosa (1964:690) commented that "the land is so thickly forested that
I have not discovered any places suitable for irrigated cultivation". And Father Casanas reports that "this province of the Hasinai is very fertile, so much that anything that one might want can be grown in it. . . . It only has one fault, which is that it is so thickly forested with different kinds of trees, and the open places are very few" (Swanton 1942:241).

Historic accounts also indicate that during part of the year the flooding of rivers presented as significant a barrier to travel as did the dense forest. The most difficult period of travel was in the fall. This coincides with one of the two peak rainfall periods for eastern Texas, which is in late September or October, the other peak period occuring in May. In 1689, a Jumano Indian being questioned by Spanish authorities investigating French activity on the Gulf coast, was questioned about the approach to the country of the Hasinai. He replied, "when the rains begin it is not easy to enter or come out of that land because of the flooded rivers and marshes which do not permit passage. . . . After it begins to rain in those parts it is not possible to come out until winter sets in" (Hackett 1926:273). Father Massanet (Gomez Canedo 1964:309) wrote, in 1693 , to the Viceroy Conde de Galve, explaining why a promised report from the province of the Hasinai, which he had sent in the care of two soldiers in October, was several months late. "It pleased the majesty of God, " he explained, "that the Colorado River would not allow them to pass, nor lessen its flow until the past month of April." Fathers Margil de Jesus and Espinosa similarly wrote in $\mathbf{1 7 2 2}$ that "because of the timing of the rise of the waters that for much of the year are an impediment to travel. . . the supply of provisions is not very abundant for the poor missionaries. ${ }^{22}$ And in 1729, several missionary priests working among the Hasinai complained of the passage from San Antonio to the Hasinai, "with two formidable rivers in between, which rarely allow passage without a canoe, and one which frequently exceeds three leagues in width; and another fifteen or more arroyos that make the road impassible. ${ }^{n 3}$ 
The combination of the dense forest and the sometimes impassible rivers made travel in the country of the Hasinai always difficult, and sometimes impossible, for anyone unfamiliar with the territory, whether they be horseback raiders from the plains, or Franciscan priests from New Spain. As the Apaches, supplied with horses taken from the Spanish settlements of New Mexico, expanded their hunting territory on the plains, threatening all challengers, such a country would have provided a particularly attractive homeland for displaced or remnant Caddoan groups from the country farther north and west. This is not to suggest that this is why the location was originally chosen for the Hasinai settlements. Caddoan peoples had occupied that area long before horses were introduced to the plains peoples. However, in the early- to midseventeenth century, when those Plains peoples began their rapid expansion, this quality of the country around the Neches and Angelina could hardly have been overlooked by Caddoans who had previously occupied the less densely forested, more exposed territory to the north and west, on the frontier of the plains.

One other aspect of the geographic position of the Hasinai Confederacy may have exerted an equally strong attractive pressure for Caddoan peoples who occupied eastern Texas during the protohistoric period. Although archaeological data is not conclusive on this point, there is strong historic evidence that during the mid- to late-seventeenth century, the Hasinai communities were a gateway for trade in European goods and horses brought from Spanish settlements in northern Mexico and New Mexico.

Evidence exists for trade contacts between the East Texas Caddo and the regions to the west, particularly the Puebloan area of New Mexico, in both the archaeological and the historical records. Timothy Baugh (1992:2) has noted that the search for archaeological evidence of Caddoan and Puebloan interaction has been somewhat frustrating, in light of the tantalizing documentary evidence from the de Soto expedition that the east Texas Caddo possessed Puebloan textiles and turquoise (Elvas 1925:246). It is likely, however, that the major commodities of this trade were perishable items that do not show up in the archaeological record, such as osage orange bow wood from the Caddo area and, as noted, cotton textiles from New Mexico. Lithics and ceramics of southwestern origin found in the Caddoan area indicate that such trade took place, but they have been recovered in such small quantities that, according to Baugh (1992:3), they are of little help in defining the nature and extent of Southwest-Caddoan interaction.

Alex Krieger (1946:209) has identified three lines of evidence for prehistoric trade between the east Texas Caddoan and Puebloan regions. These are: first, the historical evidence of the presence of trade items from the de Soto narratives; second, the recovery of a small amount of ceramics from Caddo sites in eastern Texas; and third, similarities in Puebloan and Caddoan ceramics during the fifteenth century, possibly indicating the imitation of Caddoan styles in the Puebloan area. Evidence of this prehistoric longdistance trade is most frequently found in Titus focus sites, which correspond to the late prehistoric cultures of the Cypress Creek area of northeast Texas, between the Hasinai and Red River Caddo (Kadohadacho) regions (Krieger 1946: 207). The Cypress Creek region was the site of Caddoan settlements organized similarly to the Hasinai and Kadohadacho during the late prehistoric and protohistoric periods, but was abandoned during the seventeenth century, probably by 1680 (Thurmond 1985). As I have noted, groups formerly residing in the Cypress Creek region may have become part of the Hasinai Confederacy, beginning in the mid-seventeenth century.

Story (1981:150) has suggested that the Davis and Sanders sites, located at the western edge of the eastern Texas Caddo region, were strategically placed to control incoming trade from the west, and thus are consistent with Kenneth Hirth's gateway community model (Hirth 1978). Hirth's model suggests that the emergence of social stratification is related to the control of the 
distribution of resources. When interregional trade is important to the growth of a region, Hirth says, "the most influential communities will tend to develop and be situated at strategic locales for controlling the flow of merchandise." These locales are found at points of passage into and out of the region which serve as "gateways" linking the region to external trade networks (Hirth 1978:37).

Early documentary evidence suggests that the control of such trade gateways may have developed and become important as a basis or source of reinforcement for the status of political elites among the Hasinai by the mid- to late-seventeenth century. In 1676, the Bishop of Guadalajara, Don Manuel Fernandez de Santa Cruz (Bannon 1964:112-113), on a visit of inspection to the northern frontier of New Spain, wrote of eyewitness reports from Coahuiltecan Indians of southern Texas concerning the province of the Hasinai, which had yet to be visited by the Spanish. He noted that the Coahuiltecans had communicated

"with the people of that nation, which they call Texas, and who, they maintain, live under an organized government, congregated in their pueblos, and governed by a casique who is named by the Great Lord, as they call the one who rules them all, and who, they say, resides in the interior. They have houses made of wood, cultivate the soil, plant maize and other crops, wear clothes, and punish misdemeanors, especially theft. The Coahuiles do not give more detailed reports of the Texas because, they say, they are allowed to go only to the first pueblos of the border, since the Great Lord of the Texas does not permit foreign nations to enter the interior of his country. There are many of these Coahuiles who give these reports, and who say that they got them through having aided the Texas in their wars against the Pauit, another very warlike nation."
The reason given by these Indians for having visited the Hasinai was that of aiding them in their wars. This may well have been the case. However, it is very likely, as Swanton (1942:36) notes, that an additional, and perhaps the more frequent, reason for the visits was to trade Spanish horses and merchandise. These two activities, trade and military alliance, were probably related. The Hasinai actively sought allies for warfare, and trade relationships probably served at least in part to establish military alliances. Indeed, it may have been expected that a partner in trade would also be an ally in war.

The Jumanos are most frequently mentioned as middlemen who brought Spanish goods to the Hasinai. However, there is no reason to suppose that other groups, including the Coahuiltecans, were not involved in this trade network as well. Jumano groups, displaced from the southern Plains, are known to have been present in northern Coahuila around the time of the report cited above (Campbell 1983:348; N.P. Hickerson 1994:178), and Coahuiltecan groups resident in that area may have accompanied the Jumanos on their trading visits to eastern Texas. Indeed, the "Coahuiles" mentioned by the Bishop of Guadalajara may have even included Jumanos. European observers, including the members of the Teran de los Rios expedition of 1691-92, noted the presence of members of a number of other tribes, probably "Coahuiltecan", who accompanied the Jumanos on their journeys to the Hasinai around 1690 (Teran 1932: 15; Massanet 1932: 57).

If the reports concerning the Hasinai made to the Bishop of Guadalajara by the Indians were accurate, which we have no reason to doubt, then it would appear that the Xinesi (the "Great Lord" mentioned in the quote above) maintained strict control of the border regions of the Hasinai territory. The local chiefs, the Caddices, of the outlying provinces or communities of the Hasinai Confederacy, appear to have been instrumental in maintain this border control. These Caddices, or "casique(s). . . named by the Great Lord", were probably members of the same lineage as the 
Xinesi. There is no direct evidence from the historic descriptions of the Hasinai, other than this one indirect account, that the Xinesi appointed the Caddices. It is more likely that the Xinesi rose from the ranks of the Caddices, either through seniority or through personal influence - he may have been, as Kathleen Gilmore (1983:67) termed it, the "biggest big man" among big men. However, it is quite likely that the Xinesi could direct the placement of Caddices, who were probably younger relatives, among the Hasinai villages. The purpose of their control of the frontier and the points of entry into the Hasinai territory would have been, at least in part, to control the inflow and distribution of incoming trade goods.

\section{Conclusion}

Identification of the historical processes taking place in the material and social environment are important to any understanding of the influences on sociocultural changes, such as those that created the late seventeenth-century Hasinai Confederacy. It is also important to remember that such historical processes can have their origins in far-flung locations, hundreds or even thousands of miles distant from the point of observation. This paper has addressed three separate historical factors that, at the end of the protohistoric period and beginning of the historic period, were present and which exerted significant pressure on the Caddoan peoples that comprised the Hasinai Confederacy. These three processes were: the rise of Apache aggression and hostility on the southern Plains, the development of a regular trade in European goods and horses from Spanish colonial settlements in northern Mexico and New Mexico, and demographic declines due to introduced disease. I believe that all three of these processes contributed to a fourth, the migration of Caddoan populations south to the Hasinai region. This migration provided the foundation for the subsequent development, during the late protohistoric period, of a formal political alliance and nascent chiefdom that Swanton (1942) first called the Hasinai Confederacy.

The archaeological evidence for the movement of Caddoan groups from the Cypress Creek or Sabine River region to the Hasinai region is inconclusive at best, although the abandonment of the former area is well established archaeo- logically (Thurmond 1985). However, there is documentary evidence for this movement. Some of the groups found by the de Soto party near the Cypress Creek or Sulphur River appear to have moved into the Hasinai territory by the eighteenth century. These include the provinces of Nissohone, in the Sulphur River basin, and Nondacao, on the Cypress Creek (Hudson 1993: 150-151) visited by the de Soto party (Gentleman of Elvas 1925:242-243), which seem to correspond with the late-seventeenth century Hasinai communities of Nasoni and Nadaco, respectively. ${ }^{4}$

Such movements and combinations of communities would not have been particularly unusual. Ewers (1973) emphasizes that the movement of groups and their combination with other communities was a frequent response to demographic decline among the historic period Caddo, and notes that the population of a Caddo community rarely dropped below 150 before it would leave its territory and join another group. Of course, the population of a village would not have to drop to this critical level. Other pressures besides disease could have made it advantageous for communities to move nearer to more well-positioned allies and trading partners, and thus might have been responsible for population movements.

The Spanish occupation of northern New Spain, accompanied by the introduction of Spanish goods and horses, encouraged the creation of a native trade economy centered on the movement of European goods and horses across the South- 
ern Plains, from New Mexico and far western Texas to the Caddoan region of eastern Texas. The groups involved in this trade network proba$\mathrm{bl}^{5}$ included many of the same peoples who were involved in an earlier exchange in native objects, which had brought goods from the Puebloan region to the Caddoan villages along the Red River.

However, during the late seventeenth century, middleman groups, notably the Jumano, began to follow a more southerly route across the plains than did the earlier traders, a development that was almost certainly a response to Apache expansion and aggression. As a result of this southerly shift in the native trade route across the Plains, the Hasinai communities of northeastern Texas became the eastern terminus of this route, and thus were a regional gateway for the entrance of trade goods into the Caddoan region.
Apache hostility also made it advantageous for Caddoan peoples to concentrate their settlements near the Hasinai, for its relatively protected position, for the safety to be found in numbers, and for the Spanish horses and weapons to be found there, which allowed them to meet the Apaches on relatively equal ground. The Hasinai leaders were able to use their position as a gateway for the distribution of trade goods to help them to gain a close circle of Caddoan allies, the Hasinai Confederacy, as it is now known to historians and anthropologists. They were also able to attract a looser, less formal, confederation of groups, both Caddoan and nonCaddoan, that they could count on as allies and trade partners. The desire of Hasinai and Jumano Indians, and their allies, to maintain open trade routes across the Southern Plains in the face of increasing Apache raiding would, by the late 1600 's, lead the Hasinai to encourage the establishment of Spanish missions in their territory.

\section{Endnotes}

1. Don Juan de Olivan Rebolledo, report of December 24, 1717. Bexar Archives microfilm, reel 8.

2. Letter from Fray Antonio Margil de Jesus and Fray Isidro Felix de Espinosa to the Viceroy marques de Valero, June 23, 1722. Archivo del Colegio de la Santa Cruz de Queretary, K Legajo 1 no. 18. Photocopy of transcript in Catholic Archives of Texas 2.4.11.1.

3. Fray Gabriel Vergara, et al. Representacio de los Religiosos, July 20, 1729. University of Texas, Center for American History. Transcript of original in Archivo General de la Nacion de Mexico, Box 2Q177.

4. Nasoni, during the protohistoric period, apparently split into two communities, one of which migrated to the Neches River drainage and became part of the Hainai Confederacy, and the other which became part of the Kadohadacho Confederacy on the Red River. The two communities are sometimes referred to as the Upper and Lower Nasoni.

\section{References}

Baugh, Timothy G.

1992 Regional Polities and Socioeconomic Exchange: Caddoan and Puebloan Interaction.
Paper presented at the 49th Southeastern Archaeological Conference, Little Rock, AR. 
Campbell, T.N.

1983 Coahuiltecans and their Neighbors. Handbook of North American Indians, v. 10: Southwest. Pp. 343-358. Smithsonian Institution Press, Washington, D.C.

Cox, Isaac Joslyn, ed.

1973 The Journeys of Rene Robert Cavelier Sieur de LaSalle (2 vols.). AMS Press [1905], New York.

Dobyns, Henry

1983 Their Number Become Thinned: Native American Population Dynamics in Eastern North America. University of Tennessee Press, Knoxville.

Espinosa, Fray Isidro Felix de

1964 Cronica de los Colegios de Propaganda Fide de la Nueva Espana (ed. by Lino Gomez Canedo). Academy of American Franciscan History [1746], Washington, D.C..

Ewers, John C.

1973 The Influence of Epidemics on the Indian Populations and Cultures of Texas. Plains Anthropologist 18:104-115.

Gilmore, Kathleen

1983 Caddoan Interaction in the Neches Valley, Texas. Reprints in Anthropology, v. 27. J\&L Reprints, Lincoln.

Gomez Canedo, Lino, ed.

1968 Primeras Exploraciones y Poblamiento de Texas (1686-1694). Publicaciones del Instituto Tecnologico y de Estudios Superiores de Monterrey, Monterrey, Mexico.

Hackett, Charles W., ed.

1937 Historical Documents Relating to New Mexico, Nueva Vizcaya, and Approaches Thereto, to 1773,3 vols. Carnegie Institution of Washington, Pub. 330.

Hatcher, Mattie Austin, ed.

1927 Descriptions of the Tejas or Asinai Indians. Southwestern Historical Quarterly 30(3):
206-218; 30(4): 283-304; 31(1): $150-180 ; 31(2)$ : $50-62$.

Hatcher, Mattie Austin, ed.

1932 The Expedition of Don Domingo Teran de los Rios into Texas. Preliminary Studies of the Texas Catholic Historical Society 2(3).

Hickerson, Nancy P.

1994 The Jumanos: Hunters and Traders of the South Plains. University of Texas Press, Austin.

Hirth, Kenneth G.

1978 Interregional Trade and the Formation of Gateway Communities. American Antiquity 43:35-46.

Hudson, Charles

1993 Reconstructing the de Soto Expedition Route West of the Mississippi River: Summary and Contents. In G.A. Young and M.P. Hoffman (editors), The Expedition of Hernando de Soto West of the Mississippi, 1541-1543. Pp. 143-153. University of Arkansas Press, Fayetteville.

Hyde, G.E.

1959 Indians of the High Plains: From the Prehistoric Period to the Coming of Europeans. University of Oklahoma Press, Norman.

Krieger, Alex D.

1946 Culture Complexes and Chronology in Northern Texas: With Extension of Puebloan Datings to the Mississippi Valley. University of Texas Press, Austin.

Lewis, Theodore H. (ed.)

1925 The Narrative of the Expedition of Hernando de Soto, by the Gentleman of Elvas. Pp. 127-272. In Spanish Explorers in the Southern United States, 1528-1543. Charles Scribner's Sons, New York.

McCormick, Olin F. III

1973 Archaeological Resources in the Lake Monticello Area of Titus County, Texas. Southem Methodist University Contributions in Anthropol- 
ogy, no. 8. Department of Anthropology, Southern Methodist University.

Newcomb, W.W., Jr.

1916 The Indians of Texas: From Prehistoric to Modern Times. University of Texas Press, Austin.

Pertula, Timothy K.

1991 European Contact and its Effects on Aboriginal Caddoan Populations between A.D. 1520 and A.D. 1680 . In D.H. Thomas (editor), Columbian Consequences, v. 3: The Spanish Borderlands in Pan-American Perspective. Pp. 501-518. Smithsonian Institution Press, Washington, D.C.

Perttula, Timothy

1992 The Caddo Nation: Archaeological and Ethnohistoric Perspectives. University of Texas Press, Austin.
Story, Dee Ann

1981 An Overview of the Archaeology of East

Texas. Plains Anthropologist 26:139-156.

Swanton, John R.

1942 Source Material on the History and Ethnology of the Caddo Indians. Smithsonian Institution, Bureau of American Ethnology Bulletin 132. Washington, D.C.

Thomas, Alfred Barnaby (ed.)

1982 Alonso de Posada Report, 1686: A Description of the Area of the Present Southern United States in the Seventeenth Century. The Perdido Bay Press, Pensacola.

Thurmond, J. Peter

1985 Late Caddoan Social Group Identification and Sociopolitical Organization of the Upper Cypress Basin, Northeastern Texas. Bulletin of the Texas Archeological Society 54:185-200. 